\title{
Analysis on Corrosion Fracture of Guyed Rod of Cable Stayed Iron Tower in 110 kV Transmission Line
}

\author{
Hao Chen*, Xuechao Zhang, Xiao Liu, and Xin Qiao \\ Inner Mongolia Electric Power Science \& Research Institute, Hohhot, Inner Mongolia, 010020, China
}

\begin{abstract}
The guyed rod is of great importance for supporting tower and resisting wind pressure, and its reliability is an effective guarantee for safe and stable operation of power grid. In this paper, the fractured guyed rod used for cable stayed iron tower in a $110 \mathrm{kV}$ transmission line was investigated by means of macro-morphology inspection, chemical composition analysis, microstructure analysis, scanning electron microscope, mechanical properties test, soil physicochemical properties inspection and energy spectrum analysis. The result showed that electrode potentials difference existed between different parts on the surface of the guyed rod caused by the uneven distribution of oxygen concentration was the major reason for electrochemical corrosion. Under the action of oxygen concentration cell, the effective cross-sectional area of the guyed rod decreased below the critical value, leading to the final fracture of the guyed rod.
\end{abstract}

\section{Introduction}

Guyed tower is widely used in power transmission lines owing to its advantages of light weight, less tower material consumption and convenient construction. As a key part of the cable stayed iron tower, the guyed rod plays a crucial role in supporting the tower and resisting the wind pressure, which is of great importance for the safe and stable operation of the transmission line [1]. The bottom of the guyed rod is connected with the guyed plate and buried underground together. Under the influence of various factors in the soil, chemical corrosion and electrochemical corrosion of the guyed rod is inevitable. Once the guyed rod corroded, its effective cross-sectional area would be reduced, resulting in the decrease of bearing capacity. When encountering extreme weather such as strong wind and blizzard, the break of transmission line and even the damage of guyed tower would occur owing to insufficient bearing capacity, which would seriously affect the safety and stability of the power grid. Therefore, in order to ensure the reliability of transmission line, more and more attention has been paid to corrosion and protection of guyed rod buried in the soil.

In recent years, scholars at home and abroad have carried out a lot of research on soil corrosion of metal material and have obtained great achievements in this field. Muhammad [2] summarized the factors causing corrosion of buried pipes in soils and found that corrosion rate of pipes increased with moisture contents up to the critical moisture value. Yazici [3] studied the effect of carbonitriding on the corrosion resistance of steel $30 \mathrm{MnB} 5$ in two acidic environments and revealed that the rate of corrosion of the steel after carbonitriding in both environments was lower than that after quenching. Shao [4] investigated the effects of ironaluminum oxides on the corrosion behavior of the cross section of copper-clad steel in the red soil and concluded that the iron-aluminum oxides could promote the corrosion of copper-clad steel in the red soil. Lin [5] studied the corrosion behavior of the coated Q235 steel samples in two simulated soil solutions by potentiodynamic polarization and electrochemical impedance spectroscopy methods and found that the corrosion of the matrix Q235 steel in both simulated solutions was remarkably inhibited by $\mathrm{Zn}$ and $\mathrm{Zn} 15 \mathrm{Al}$ coatings.

Because the guyed rods are buried underground all the year round, it is difficult to determine its corrosion degree by routine inspection of transmission lines. In addition, due to the polyphase and inhomogeneity of the soil, the corrosion behavior of guyed rod is extremely complex and affected by many factors, which makes it difficult to study the corrosion and protection of guyed rods. In this paper, the cause of corrosion fracture of the guyed rod used for cable stayed iron tower in a $110 \mathrm{kV}$ transmission line was investigated by means of different test methods. Meanwhile, the corrosion mechanism and characteristics of the guyed rod in the soil were systematically studied and summarized. Finally, effective suggestions were put forward, which could provide theoretical basis for corrosion and protection of guyed rod.

\section{Experiment results and analysis}

\subsection{Macroscopic observation}


The $110 \mathrm{kV}$ guyed tower is located in the pastoral area without any industrial pollution. The guyed rod is made of $\mathrm{Q} 235 \mathrm{~B}$ with the diameter of $18 \mathrm{~mm}$ and hot dip galvanizing layer is adopted as anticorrosive coating. Through excavation inspection, it is found that the underground part of guyed rod has fractured and corroded seriously, without obvious elongated deformation. Meanwhile its surface has been completely covered with brown corrosion products, which illustrates that the zinc coating has totally depleted, as shown in figure 1. Additionally, the cross-section area of the stay guyed rod near the fracture is reduced by $70 \%$ due to soil corrosion, leading to a significant decrease in the bearing capacity. However, the above ground part of the guyed rod is almost free of corrosion, and the galvanized layer is relatively intact.

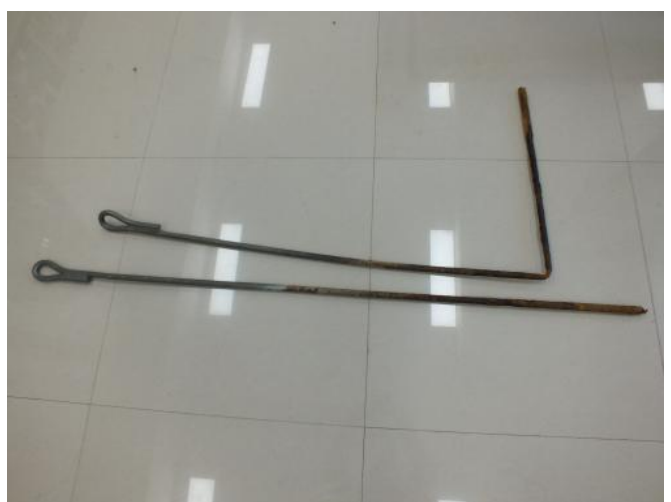

(a)Entirety

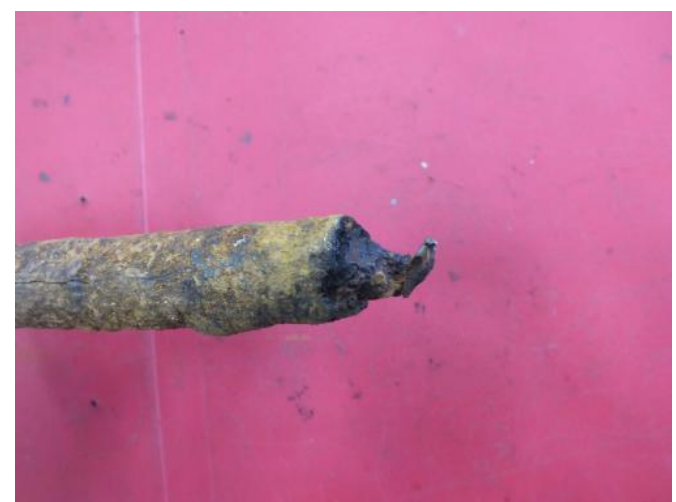

(b) Fracture

Figure 1 The macro morphology of the corroded guyed rod.

\subsection{Metallographic structure Analysis}

Figure 2 shows the metallographic microstructure of the corroded guyed rod. In the cross section near the fracture, the metallographic structure of the guyed rod is mainly polygonal ferrite and equiaxed pearlite, without abnormal microstructure. Meanwhile, there are many corrosion pits in different sizes and depths on the surface of the corroded guyed rod. In addition, the thickness of zinc coating on the above ground part of the guyed rod is determined as $86 \mu \mathrm{m}$ by metallographic method.

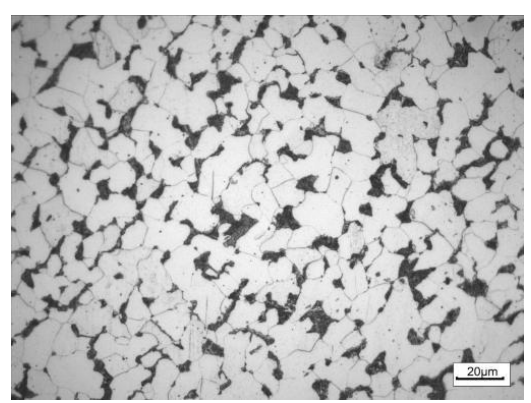

(a) Matrix

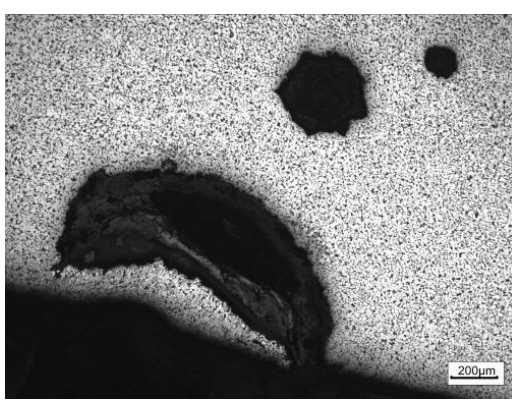

(b) Corrosion pits

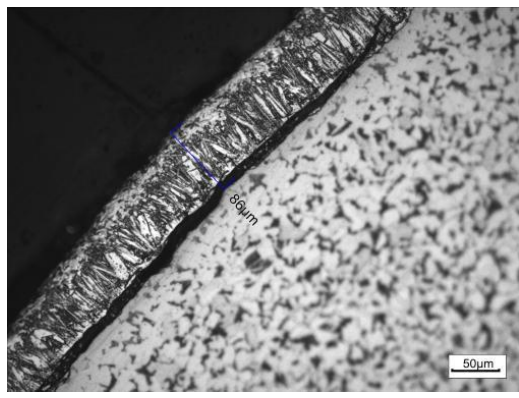

(c) Zinc coating

Figure 2. The metallographic structure of the guyed rod.

\subsection{Chemical composition analysis and hardness testing}

The chemical compositions of the corroded guyed rod are determined by means of chemical composition analysis and the testing result (mass fraction) is shown in Table 1. The result shows that the contents of each element meet the requirement of standard GB / $\mathrm{T}$ 7002006 for Q235B steel.

Table 1. Chemical analysis result of the corroded guyed rod ( $\mathrm{wt} \%$ )

\begin{tabular}{cccccc}
\hline Chemical element & $\mathrm{C}$ & $\mathrm{Si}$ & $\mathrm{Mn}$ & $\mathrm{P}$ & $\mathrm{S}$ \\
\hline Standard requirements & $\leqslant 0.22$ & $\leqslant 0.35$ & $\leqslant 1.40$ & $\leqslant 0.045$ & $\leqslant 0.050$ \\
Test values & 0.17 & 0.22 & 0.51 & 0.011 & 0.018 \\
\hline
\end{tabular}

\subsection{Microstructure and energy spectrum analysis of corrosion products}

The micro morphology of the corrosion products sampled from the corroded guyed rod is investigated by means of scanning electron microscope (SEM) and the result is shown in Figure 3. It is clearly observed that the 
surface of the corroded guyed rod is covered with a large number of corrosion products, which are loose and porous cluster particles with different size.

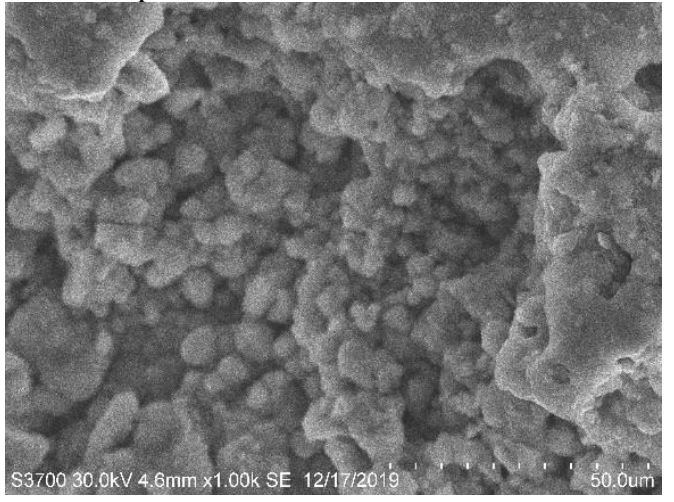

Figure 3. The SEM morphology of corrosion products.

The chemical compositions of the corrosion product on the surface of the corroded guyed rod are analysed by energy spectrum analyser, and the testing result is shown in Figure 4. The result illustrates that the corrosion product mainly contains iron and oxygen without other elements, which should be iron oxide.

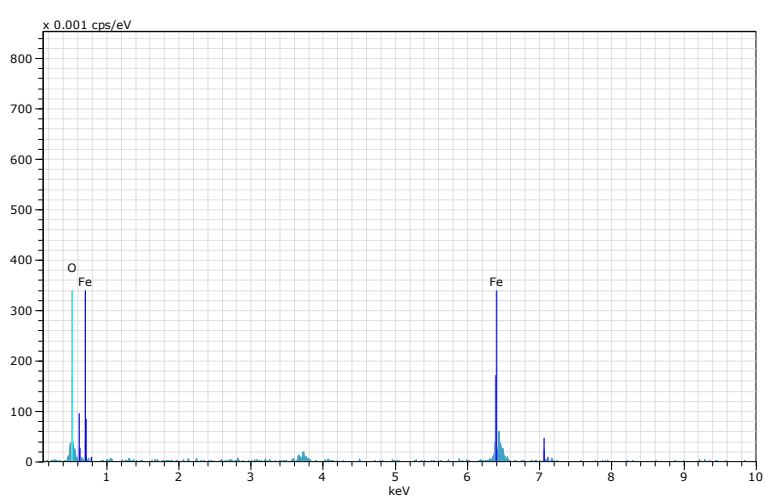

Figure 4. Energy spectrum analysis chart for corrosion product.

\subsection{Physicochemical properties testing of soil sample}

Table 2 shows the test result of physical property and ion content of the soil samples around the guyed tower. The result shows that the sulfate anion and chloridion contents of the soil are $0.198 / \mathrm{kg}$ and $0.163 \mathrm{~g} / \mathrm{kg}$ respectively, with the salinity being $0.154 \%$. In addition, the soil water content is $3.26 \%$, and its $\mathrm{pH}$ value is 8.35 . The terrain around the tower is relatively flat without industrial pollution, so the alkaline soil sample presents weak corrosiveness.

Table 2. The test result of physical property and ion content for soil sample

\begin{tabular}{ccccccc}
\hline Test item & $\mathrm{SO} 42-/(\mathrm{g} / \mathrm{kg})$ & $\mathrm{Cl}-/(\mathrm{g} / \mathrm{kg})$ & $\mathrm{NO} 3-/(\mathrm{g} / \mathrm{kg})$ & $\mathrm{pH}$ & Water content $/ \%$ & Salinity $/ \%$ \\
\hline Test values & 0.198 & 0.163 & 0.099 & 8.35 & 3.26 & 0.154 \\
\hline
\end{tabular}

\subsection{Mechanical properties testing}

The mechanical properties of the corroded guyed rod are tested by universal tensile testing machine and hydraulic pendulum impact testing machine at room temperature and the testing result is shown in Table 3. The result shows that the yield strength, tensile strength, percentage elongation after fracture and impact absorption energy of the guyed rod meet the requirement of standard GB / T 700-2006.

Table 3. The test result of mechanical properties of the corroded guyed rod $\left(20^{\circ} \mathrm{C}\right)$

\begin{tabular}{ccccc}
\hline Test item & $\begin{array}{c}\text { Yield } \\
\text { strength } / \mathrm{MPa}\end{array}$ & $\begin{array}{c}\text { Tensile } \\
\text { strength } / \mathrm{MPa}\end{array}$ & $\begin{array}{c}\text { Percentage elongation } \\
\text { after fracture } / \%\end{array}$ & $\begin{array}{c}\text { Impact absorption } \\
\text { energy } / \mathbf{J}\end{array}$ \\
\hline $\begin{array}{c}\text { Standard } \\
\text { requirements } \\
\text { Test values }\end{array}$ & 318 & $370 \sim 500$ & $\geqslant 26$ & $\geqslant 27$ \\
\hline
\end{tabular}

\section{Analysis and discussion}

As the corrosion medium, the soil is heterogeneous and inhomogeneous, which is composed of solid, liquid and gas. Meanwhile, the corrosion behaviour of guyed rod is extremely complex, which is influenced by water content, $\mathrm{pH}$ value, soluble salt concentration, microorganism and temperature and climate conditions $[6,7]$.

In substance, soil corrosion of guyed rod could be regarded as electrochemical corrosion. Due to the inhomogeneity of soil medium, the physical and chemical properties of each point are significantly different, so the potential difference of each part in guyed rod is different, leading to the corrosion reaction of primary battery. Generally, the electrochemical corrosion of guyed rods in neutral or alkaline soil could be divided into cathodic corrosion process and anodic corrosion process. Thus, iron as anode dissolves continuously and the depolarization reaction of oxygen occurs at the cathode $[8,9]$. The specific reactions are as follows:

Anodic reaction: $\mathrm{Fe} \rightarrow \mathrm{Fe}^{2+}+2 \mathrm{e}$

Cathodic reaction: $\mathrm{O}_{2}+2 \mathrm{H}_{2} \mathrm{O}+4 \mathrm{e} \rightarrow 4 \mathrm{OH}^{-}$

The overall reaction:

$$
2 \mathrm{Fe}+\mathrm{O}_{2}+2 \mathrm{H}_{2} \mathrm{O} \rightarrow 2 \mathrm{Fe}(\mathrm{OH})_{2}
$$


When oxygen is present at the anode, ferrous hydroxide $\left(\mathrm{Fe}(\mathrm{OH})_{2}\right)$ could react with oxygen and water to produce ferric hydroxide $\left(\mathrm{Fe}(\mathrm{OH})_{3}\right)$, and the reaction equation is described as follows:

$$
4 \mathrm{Fe}(\mathrm{OH})_{2}+\mathrm{O}_{2}+2 \mathrm{H}_{2} \mathrm{O} \rightarrow 4 \mathrm{Fe}(\mathrm{OH})_{3}
$$

However, the structure of ferric hydroxide $\left(\mathrm{Fe}(\mathrm{OH})_{3}\right)$ is very unstable, and it would be further transformed into more stable ferric hydroxide ( $\mathrm{FeOOH}$ ) or ferric oxide $\left(\mathrm{Fe}_{2} \mathrm{O}_{3}\right)$. The specific transformation process is as follows:

$$
\begin{gathered}
\mathrm{Fe}(\mathrm{OH})_{3} \rightarrow \mathrm{FeOOH}+\mathrm{H}_{2} \mathrm{O} \\
2 \mathrm{Fe}(\mathrm{OH})_{3} \rightarrow \mathrm{Fe}_{2} \mathrm{O}_{3} \cdot 3 \mathrm{H}_{2} \mathrm{O} \rightarrow \mathrm{Fe}_{2} \mathrm{O}_{3}+3 \mathrm{H}_{2} \mathrm{O}
\end{gathered}
$$

The $110 \mathrm{kV}$ guyed tower is set up in the flat pastoral area without any industrial pollution, around which the salinity of the soil is relative lower. Thus, the contribution of soluble salt to the soil corrosion of the guyed rod is very limited. As a result of polyphase and inhomogeneity, there are obvious differences in porosity and humidity in different depths of the soil. In the dry and loose sandy soil of the surface layer, oxygen is easier to penetrate, which makes the oxygen concentration higher. With the increase of burial depth, the soil becomes more and more humid and compact, making it difficult for oxygen to pass through, so the oxygen concentration decreases obviously [10]. Thus, owing to great difference in oxygen concentration, the part of guyed rod buried in the soil is corroded under the action of oxygen concentration battery $[11,12]$, and the specific corrosion process would be carried out according to the above reaction equation. For the guyed rod, the part contacting with the soil of higher oxygen content is considered as cathode of macro corrosion battery, while the part buried deeper is regarded as cathode due to lower oxygen concentration and suffers from serious corrosion. Therefore, the effective cross-sectional area of the part buried in the deeper soil decreases continuously owing to the soil corrosion of the guyed rod, which leads to a great decrease of bearing capacity. Finally, the guyed rod cracks under the action of tensile stress.

\section{Conclusions}

In this paper, the reason for corrosion fracture of the guyed rod was systematically investigated and analysed. Through comparing and analysing the experimental results, the following conclusions are drawn.

1) Because of the uneven distribution of oxygen concentration in the soil, the electrode potential of each part in the guyed rod is different, resulting in soil corrosion of oxygen concentration cell. With the continuous corrosion, as a result, the cross-sectional area and bearing capacity of the guyed rod decreases gradually. Under the action of tensile stress, the guyed rod eventually breaks due to insufficient bearing capacity.

2) As the guyed rod is buried underground, it is difficult to find the existing defects in the routine inspection of transmission lines. At present, guided wave detection technology and electromagnetic ultrasonic detection technology have been successfully applied to the corrosion defect detection of grounding grid and anchor bolt, which could be considered as the same in the corrosion detection of guyed rod.

3) The method of nesting the guyed rod into a PVC pipe could effectively isolate it from corrosive substances in air and soil, which would play a good anticorrosion role. Moreover, epoxy resin and zinc aluminum alloy with stronger corrosion resistance could be considered as anticorrosive coating, in order to ensure the safety and stability of transmission line.

\section{Acknowledgments}

The authors would like to acknowledge the financial support from the Science and Technology Project of Inner Mongolia Power Company (Grant No. 2019-102).

\section{References}

1. Zuo, X., Gao, B. (2010) Guyed poles protection measurements of guyed tower in transmission lines. Jilin Electric Power, 38: 50-51.

2. Muhammad, W., Shahrukh, S., Mubarak, N.M., Inamuddin, Asiri, A.M. (2018) Factors influencing corrosion of metal pipes in soils. Environmental Chemistry Letters, 16: 861-879.

3. Yazici, A., Zeybek, M.S., Güler, H., Koç, M., Pekýtkan, F.G. (2017) Effect of carbonitriding on corrosion resistance of steel $30 \mathrm{MnB} 5$ in two acidic environments. Metal Science and Heat Treatment, 59: 190-193.

4. Shao, Y.P., Mu, M.M., Zhang, B., Nie, K.B., Liao, Q.Q. (2017) Corrosion behavior of copper-clad steel bars with unclad two-end faces for grounding grids in the red clay soil. Journal of Materials Engineering and Performance, 26: 1751-1757.

5. Lin, B.L., Lu, X.Y., Li, L. (2011) Electrochemical corrosion behavior of arc sprayed $\mathrm{Zn}$ and $\mathrm{Zn} 15 \mathrm{Al}$ coatings in simulated salina soil and neutral meadow soil solutions. Journal of Wuhan University of Technology-Mater. Sci. Ed., 26: 1152-1156.

6. Li, M., Shi, Z.M, Liu, Y.B. (2013) Crevice corrosion of K60 in dry desertification saline soil. Journal of Iron and Steel Research International, 20: 76-80.

7. Glazov, N.N., Ukhlovtsev, S.M., Reformatskaya, I.I., Podobaev, A.N., Ashcheulova, I.I. (2006) Corrosion of carbon steel in soils of varying moisture content. Protection of Metals, 42: 601-608.

8. Ding, C.J., Yang, H.X., Wang, J.D., M, B., Song, C., Xu, X.G., Cui, L.K., Bi, K.D. (2019) Corrosion and protection of materials for grounding grid. Corrosion Science and Protection Technology, 31: 109-113.

9. Karthick, S., Muralidharan, S., Saraswathy, V. (2020) Corrosion performance of mild steel and galvanized iron in clay soil environment. Arabian Journal of Chemistry, 13: 3301-3318. 
10. Schimmack, W., Gerstmann, U., Schultz, W., Geipel, G. (2007) Long-term corrosion and leaching of depleted uranium (DU) in soil Radiation and Environmental Biophysics, 46: 221-227.

11. Andreikiv, O.E., Hembara, O.V. (2013) Influence of soil corrosion and transported products on the service life of welded joints of oil and gas pipelines. Materials Science, 49: 189-198.

12. Zhu, Z.P., Shi, C., Zhang, Y., Liu, Z.F. (2020) The effects of $\mathrm{Cl}-$ and direct stray current on soil corrosion of three grounding grid materials. AntiCorrosion Methods and Materials, 67: 73-82. 